alopted. Your correspondent has omitted this very important proviso:

Provided, (a) That all applicants for membership shall be re quired to state in writing that they do not accept any sectarian title of base their practice on any exclusive dogma or system : and ib) must satisfy the censors that ther possess the requisite scien-
tific and technical education and gullifications.

Obviously your correspondent is in error in stating that "practitioners of all schools of medicine" will now be eligible for membership in the county society. On the contrary, any one who terms himself an adherent of any particular "school" or "sect," old or new, or allows his patients so to designate him, will be ineligible. The Philadelphia County Medical Society will not become pan-sectarian, but insists on remaining non-sectarian.

It does, however, recognize the fact that the word "regular" as applied to physicians and medical colleges, has become offensive and obsolete, and that all persons of good character, adequately trained and legally qualified to practice medicine, should be admitted to the society, and throngh it to the Medical Society of the State of Pemnslvania and the Ameriean Medical Association; provited only, that such persons shall be content with the honorable title of physician, neither adrling thereto nor diminishing therefrom, by any epithet or adjective.

The society does not seek to control or to limit in any way, whether by prescription or by proseription, the theories or the practice of its members; but it cloes not invite into fellowship those who voluntarily so fetter themselves by formula or dogma, as to impede their own adrance in knowledge, or deprive their patients of the benefits of discovery and progress.

I may also call your attention to a minor error in the report. The credit of introducing this amendment does not belong to me, as stated by your correspondent, but rather to Dr. John B. Roberts, who has for many years been a consistent champion of such action, and with whom were associated Drs. Alber' M. Eaton, Henry Beates and others. Mr own part consisted simply in a modification of the phrascology of the proposition. A majority of the more conservative members believed with me, that while erery earnost truthseeker in medicine should be welcomed unconditionally, yet those who are conscientiously bound and blinded by narrow systems, or who, for commercial purposes, prefer to retain the sectarian trade-mark, would neither strengthen the society nor derive benefit from membership therein.

I have not thought it becoming or worth while to correct the many misstatements that have gotten into the Philadelrhia newspapers concerning this matter and my connection with it, but reports in Trie Journal of the American Medical Association go to make medical history, and may perhaps influence the action of other societies. It is, therefore, desirable that they should be accurate. Solomon Solis-Colien.

\section{The Proposed American Medical Cyclopedia.}

BALTIMORE, Oct, 29, 1907 .

To the Editor: It may interest those who showed interest in the scheme of my proposed Cyclopedia of American Medical Biography to learn that 150 biographies have been sent in and over a hundred more promised. The pleasant and willing cooperation of phrsicians in all states argues well for the ultimate success of the book, but helpers are lacking for the Carolinas, Nevada, Utah and Arizona. Pictures, photographs and signatures of medical worthies are also still needed.

In order that full credit shall be given to men who have been eminent in any particular way, fourteen of my confrires have undertaken to write up specialists, and a chapter will be revoted to those who have excelled in any science besides that of medicine. Dr. Bardeen (Wisconsin) sends in a suggestive list of anatomists :

\begin{tabular}{|c|c|}
\hline \multicolumn{2}{|l|}{ ebster. } \\
\hline D. Welts. & iv forbes. \\
\hline w. H. White. & $\therefore$ Ia Ford. \\
\hline T. Wilson. & I. D. Todman. \\
\hline C. Wistar. & R. Harlan. \\
\hline 1. Nyman. & F. II. IIartwell. \\
\hline II. Allen. & C. Ileitzmann. \\
\hline J A Allen. & o. W. Ilolmes. \\
\hline $\begin{array}{l}\text { Sohr, Bard. } \\
\text { Beck (of Alhany) }\end{array}$ & T. Ilewson. \\
\hline Ang Rernays. & iv. Ifunter. \\
\hline Dr Brintor. & A. T. Iautermann. \\
\hline c. Carmalt. & J. V. O. Ia awrence. \\
\hline Tustus Dun & P. Midaleton. \\
\hline
\end{tabular}

Tohn Molman.

S. A. Mortion.

R. D. Mussey

J. Pancoast.

G. Parish.

G. S. Pattison.

Cyrus Perkins.

P. S. Physick.

Ii. D. Saterthwaid.

w. shippen.

Nathan Nmith.

J. K. Tharles.

Joln warren
I fully appreciate the difficulty of getting the human sidethe little personal traits and anecdotes-of men long since dead, but there are many relations and friends of men dead within the last fifty years who, from their own personal recollections, conld supplement the often unavoidably dry biographies in medical journals. HowaRd A. KELly.

\section{Queries and Minor Notes}

Axorrmoes Comunicatioxs will not be noticed. Queries for this column nust be accompanied by the writer's name and addiess, but the request of the wrifer not to publish name or address will be faithfully observed.

\section{CONSTITLENTS OF KUTNOW'S POWDER AND "MILES NERVINE."}

ElmiRa, N. Y., Oct. 23, 1907.

To the Editor:- Will you please give me the constituents of Katnow's powder and Ur. Miles' nervine and oblige.

\section{J. I. IHERRICK, M.I.}

Axswre-According to circulars distributed to physicians in this country, Kutnow's I'owder is "composed of the ingredients of the celebrated Carlsbad spring. The analysis of our effervescent powder is exactly like that of the spring, with one exception that we have added a very small amount of saccharin in order to malie it palatable." According to an analysis made in Germany, however, nearly half (43.6 per cent.) of Kutnow's l'owder is tartaric acid. I'resumably this is put in for effervescent purposes, and presumably also Kutnow Brothers did not think it worth while to mention this. Tartaric acid is not found in the natural Carlsbad water. The analysis above referred to is contained in a report of the investigations made in the State Institution for the Investigation of Foodstuffs, etc., for the district of Berlin. (Mitteilung aus a') staatlichon Anstalt zur Untersuchung ion Nahrungs und Gomussm. teln sowic Gebrauchsgegenstänten für len Landespolisebesil. Berlin Juckenack (A.) and Griebel (K.): Berirhte der Deutseh(n Pharmasentischen Gescllschaft, xvii, No. 6, p. 275.) The following is a translation: "ISutnow's Improved Fffervescent Carlsbid l'owder': In the powder were found: Tartaric acid 43.6 per cent., carbonic acid $\left(\mathrm{CO}_{2}\right) 14.27$ per cent., sulphuric acid $\left(\mathrm{SO}_{3}\right) 4.27$ per cent., sodium oxid ( $\left.\mathrm{Na}_{2} \mathrm{O}\right) 20.39$ per cent, potassium oxid (K.0) s.s? per cent., chlorin (Cl) 1.82 per cent." From this we may conclude that the powder consists essentially of a mixture of tartaric acid with the carbonates, sulphates, and chlorids of potassium and sodium. After effervescence has ceased we wouli find a mixture of sodium and potassium tartrate, sulphate and chlorid, the tartaric acid and the carbonates having reacted to produce the tartrate. A small amount of unchanged carbonate would remain. The amount of sulphates would be about $12 \mathrm{per}$ cent., while there would be about 75 per cent. of tartrates.

If we compare this with the composition of the Carlsbad salt we find a very considerable difference. Analysis of the Carlsbad sall shows that about 41 per cent. consists of sodium sulphate, abour $\because 6$ per cent. of sodium bicarbonate and 18 per cent. of sodium chlorid. It is plain that we cannot expect the same therapentio effects from a mixture the chief ingredient of which is soctium tartrate, which will have its principal action on the kidneys, unless given in very large doses, and one which contains as its chief active ingredient the sulphate of sodium, which acts primarily on the gastrointestinal canal.

A proprietary preparation designed to imitate the Carlsbad spring water is quite unnecessary as both the German Pharmacopeia and the National Formulary contain formulas from which such artificial salts can be made.

For the simple mixture of salts the physician may prescrilue Sal Carolinum Factitium (N. F.), and for an effervescent powder l'ulvis Salis Carolini Factitii Efrervescens (N. F.)

The composition of Dr. Miles' Nervine is not divulged, and we lnow of no published analysis of it. We would call attention to the legal decision published in THe Jonrxal, May 12, 1906, 1459, according to which the Miles Medical Co. was allowed no standing in a court of equity because of the falsity of the claims made for its remedies.

\section{VALUE OF SERLM TIIERAI'Y.}

Naxticore, Min, Oct, $15,1907$.

To the Editor:- Kindly discuss briefsy the relative ralue of antitetanic antistreptococic, antipneumococsic and other sera prepared and put out by various manufacturers. I do not mean the value of one manufacturer's product over that of another, but the value of the treatment; especially that of the antistreptococeic and antipneumococcic. 